\title{
Relationships Among Sleep Problems, Executive Function and Social Behavior During the Preschool Period
}

\author{
Nana Shin ${ }^{1}$, Bokyung Park ${ }^{2}$, Minjoo Kim ${ }^{3}$, Kibong Yun ${ }^{3}$, Sun-Young Yoon ${ }^{1}$ \\ Department of Child Development \& Intervention, Ewha Womans University, Seoul, Korea ${ }^{1}$ \\ Department of Education for Child Care, Kyungmin University, Uijeongbu, Korea ${ }^{2}$ \\ Child \& Family Research Institute, Ewha Womans University, Seoul, Korea ${ }^{3}$ \\ 유아기 수면문제, 실행기능 및 사회적 행동 간의 관계 \\ 신나나 ${ }^{1}$, 박보경 ${ }^{2}$, 김민주 $^{3}$, 윤기봉 ${ }^{3}$, 윤선영 $^{1}$ \\ 이화여자대학교 아동학과 ${ }^{1}$, 경민대학교 아동보육과 ${ }^{2}$, 이화여자대학교 아동가족연구소 ${ }^{3}$
}

Objective: This study examined the relationships among sleep problems, executive function and social behavior during the preschool period. In addition, the mediating role of executive function between sleep problems and social behavior was investigated.

Methods: A total of 304 preschool children participated in this study. The data were collected through maternal reports.

Results: First, preschoolers' sleep problems were found to be significantly related to overt aggression and prosocial behavior. Second, preschoolers with sleep problems displayed lower levels of executive function. Third, preschoolers' executive function was significantly associated with social behavior. Lastly, preschoolers' executive function fully mediated the relationship between sleep problems and overt aggression, and between sleep problems and prosocial behavior. That is, preschoolers' sleep problems had effects on overt aggression and prosocial behavior, only through the effects on executive function.

Conclusion: This study contributes to the sleep literature by examining the role of executive function and emphasizes the importance of forming a healthy sleep habit during the preschool period.

Keywords: sleep problems, executive function, social behavior, preschool period

\section{서론}

최근 영유아기 신체, 인지, 사회정서의 다양한 영역에서 최적 의 발달을 이루는데 중요한 역할을 담당하는 수면에 대한 관 심이 높아지고 있다(Astill, Van der Heijden, Van IJzendoorn, \& Van Someren, 2012; Cremone et al., 2017). 수면은 생물학적이

Corresponding Author: Bokyung Park, Department of Education for Child Care, Kyungmin University, 545, Seobu-ro, Uijeongbu-si, Gyeonggi-do 11618, Korea

E-mail: pbk0917@hanmail.net
며 행동적인 상태로, 총 수면시간이나 낮잠의 횟수, 야간 수 면길이와 같은 양적 측면과 수면패턴, 수면문제, 숙면 여부 와 같은 질적 측면이 동시에 작용하여 개인의 적응에 영향을 미친다. 수면의 중요성은 특히 유아기에 강조되는데, 이 시 기는 영아기의 불안정한 수면패턴에서 벗어나 좀 더 안정되 고 사회화된 수면패턴으로 변화하는 전환기이기 때문이다

(C)The Korean Association of Child Studies

This is an Open Access article distributed under the terms of the Creative Commons Attribution Non-Commercial License (http:// creativecommons.org/licenses/by-nc/4.0) which permits unrestricted noncommercial use, distribution, and reproduction in any medium, provided the original work is properly cited. 
(Jenni, Molinari, Caflisch, \& Largo, 2007). 특히 이 시기 전체 유 아의 25-40\% 정도가 수면문제를 경험하며(Lam, Hiscock, \& Wake, 2003; Mindell, Kuhn, Lewin, Meltzer, \& Sadeh, 2006), 이 경우 적절한 개입이 이루어지지 않으면 수면문제가 만성화 되어 학령기나 청소년기까지 이어질 수 있다(Pollock, 1994). 또한 초기의 수면문제가 정서조절에 지속적으로 부정적인 영향을 미쳐 이후 수면문제를 더 악화시키는 발달적 케스케 이드(cascade)로 작용할 가능성도 제기되고 있어(Williams, Berthelsen, Walker, \& Nicholson, 2017), 초기 올바른 수면패턴 형성의 중요성이 더욱 강조되고 있다.

유아기 수면의 중요성에도 불구하고, 수면문제가 문제행동 과 친사회적 행동을 포함한 다양한 사회적 행동에 미치는 영 향을 살펴본 연구들은 주로 학령기에 초점을 두어 이루어져 왔다. Astill 등(2012)은 5-12세의 학령기 아동을 대상으로 수 면이 문제행동에 미치는 영향을 살펴본 47편의 연구들을 메 타분석한 결과, 수면의 양이 내면화 문제행동과 외현화 문제 행동 모두와 관련된 중요한 변인임을 확인하였다. 반면 수면 의 질적 측면에 해당하는 수면의 효율성은 문제행동에 유의한 영향을 미치지 않는 것으로 나타났다. 그 원인 중 하나로 Astill 등(2012)은 포함된 47편의 연구 중 수면의 효율성을 살펴본 연구가 많지 않다는 점을 들면서 수면의 효율성에 대한 연구 가 더 이루어질 필요가 있음을 제안하였다. 이후 실시된 연구 (Simola, Liukkonen, Pitkäranta, Pirinen, \& Aronen, 2014)에서도, 학령기 동안 지속적인 수면문제를 가지고 있는 경우 공격성, 우울, 불안 등의 문제행동을 더 많이 보이며, 수면의 효율성이 주간 정서상태를 통해 외현화 문제행동과 내면화 문제행동에 영향을 미치는 것으로 보고하였다(Kouros \& El-Sheikh, 2015). 또한 수면문제를 가지고 있는 초등학생의 부모를 대상으로 2-3회의 중재 프로그램을 실시한 Quach, Hiscock, Ukoumunne 과 Wake (2011)는 프로그램을 실시하기 전에 비해 실시 후 초 등학생이 친사회적 행동을 더 많이 보였으며, 이러한 효과가 프로그램 종료 후 12 개월까지 지속되었음을 보고하였다.

유아를 대상으로 수면이 사회적 행동에 미치는 영향을 살 펴본 연구들은 그 수는 적지만, 학령기 아동을 대상으로 한 연 구들과 유사한 결과를 보고하고 있다. 구체적으로, 이러한 연 구들에서는 수면문제를 가지고 있거나 충분한 수면을 취하 지 못하는 유아는 외현화 문제행동과 내면화 문제행동을 더 보이며(Keefe-Cooperman \& Brady-Amoon, 2014; Lavigne et al., 1999), 이는 수면측정기(actigraph)를 통해 객관적으로 수면을 측정한 경우(Yokomaku et al., 2008)와 부모보고를 통해 수면을 측정한 경우(Goodlin-Jones, Tang, Liu, \& Anders, 2009; Komada et al., 2011; Scharf, Demmer, Silver, \& Stein, 2013; Whalen, Gilbert, Barch, Luby, \& Belden, 2017) 모두에서 일관적으로 보 고되었다. 특히 늦은 수면시간이 기질적인 부정적 정서성과 결합되었을 경우 내면화 문제행동과 외현화 문제행동을 보일 위험이 더 높았다(Cremone et al., 2017). 또한 유아기 불규칙적 인 수면패턴은 기관에서의 부적응과 관련이 있었으며(Bates, Viken, Alexander, Beyers, \& Stockton, 2002), 또래 수용이나 친 사회적 행동을 포함한 사회적 기술, 또래 간 상호작용 등 또 래집단 내에서의 적응에도 부정적인 영향을 미쳤다(Vaughn, Elmore-Staton, Shin, \& El-Sheikh, 2015).

수면이 사회적 행동에 미치는 영향에 더해, 수면과 인지 적 기능 간의 관련성에 대한 연구들도 보고되고 있다(Astill et al., 2012; Dewald, Meijer, Oort, Kerkhof, \& Bögels, 2010). Sadeh (2007)는 수면문제가 인지적 기능에 부정적으로 영향을 미치 는 두 가지 경로를 제안하였다. 즉, 불충분한 수면이나 비효율 적인 수면은 두뇌 성숙, 정보처리, 기억, 학습 등에 요구되는 두뇌의 활동을 감소시키며, 낮 동안 졸음을 유발하고 기민함 을 감소시킴으로써 개인의 인지 기능을 저하시킨다는 것이다. 특히 유아기에는 뇌의 성숙이 계속해서 진행되고 학습이 빠르 게 이루어지기 때문에 이러한 두 가지 경로가 함께 작용하여 수면의 영향을 극대화 시킬 수 있다. 실제 수면과 인지적 기능 간의 관련성을 살펴본 연구들을 집대성하여 메타분석을 실시 한 Dewald 등(2010)의 연구에서도 수면과 인지 기능 간의 관 계가 연령이 어릴수록 더 강하게 나타난다는 것을 확인하였 으며, 유아를 대상으로 한 연구에서도 충분한 양의 수면을 취 하지 못할 경우 인지적 기능이 저하되는 것으로 보고되었다 (Vaughn et al., 2015).

인지 기능의 다양한 지표 중 수면과 관련하여 특히 주목 받고 있는 영역이 실행기능으로, 실행기능은 성인(Jones \& Harrison, 2001)과 아동(Buckhalt, El-Sheikh, \& Keller, 2007), 영 유아(Bernier, Beauchamp, Bouvette-Turcot, Carlson, \& Carrier, 2013)를 대상으로 한 연구에서 언어나 지식과 같은 일반적인 인지 기능의 지표보다 수면과 더 관련이 있는 것으로 보고되 었다. 실행기능은 의식적으로 사고와 행동을 관리하고 조절하 는 고차원적인 인지능력을 의미하며(Zelazo, 2004), 억제, 작업 기억, 주의전환, 계획 및 조직 등의 다양한 기술들이 포함된다. 특히 유아기는 실행기능의 민감기로 묘사될 정도로 실행기능 의 발달적 전환이 이루어지는 시기로, 만 30 개월에서 72 개월 사이에 실행기능의 하위영역들은 급격하게 발달한다(Garon, Bryson, \& Smith, 2008; Zelazo et al., 2003). 그럼에도 불구하고 유아기 수면이 실행기능에 미치는 영향을 직접적으로 살펴본 
연구는 찾아보기 힘들며, 다만 영아기 수면문제가 일반적 인 지 기능을 통제한 후에도 유아기 실행기능 과제에서의 빈약한 수행을 예측하는 것으로 보고한 연구(Bernier et al., 2013)가 나 타나고 있다. 학령기를 대상으로 한 연구는 좀 더 활발하게 이 루어져 왔는데, Astill 등(2012)은 학령기 아동을 대상으로 기존 에 실시된 86편의 연구를 종합한 결과, 수면문제를 가지고 있 거나 충분한 수면을 취하지 못하는 아동은 실행기능 과제를 포함한 다양한 인지 기능 측정과제에서 빈약한 수행을 보이는 것을 확인하였다.

이렇듯 국외의 경우 유아기 수면문제가 문제행동과 친사회 적 행동을 포함한 사회적 행동과 인지 기능에 미치는 영향을 살펴본 연구가 다양한 각도에서 진행되어 왔지만, 국내의 경 우 유아기 수면습관이나 수면문제가 발달에 미치는 영향은 많 은 관심을 받지 못하였다. 이러한 경향은 최근 변화를 보여, 수 면의 양과 질이 인지, 사회, 정서발달에 미치는 영향을 살펴본 국내 연구들이 일부 나타나고 있다. 이러한 연구들에서는 수 면이 문제행동(Do, 2009; Y.-H. Kim, 2015; S.-M. Kim \& Kim, 2015; You \& Cho, 2014)이나 정서조절(You \& Cho, 2014), 또 래유능성(Yoo \& Kim, 2017), 유치원에서의 부적응 $(\mathrm{Oh} \& \mathrm{Lee}$, 2014) 등과 관련이 있음을 확인하였다. 보다 구체적으로 살 펴보면, Y.-H. Kim (2015)은 야간 수면길이가 미국수면재단 (National Sleep Foundation)이 권장한 10-13시간(Hirshkowitz et al., 2015)에 미치지 못하는 경우 외현화 문제행동이나 정서문 제를 더 보이는 것으로 보고하였으며, S. J. Kim (2015)의 연구 에서는 수면의 양은 문제행동과, 수면의 질은 인지 발달과 관 련이 있었다. 또한 You와 Cho (2014)는 수면의 질에 초점을 두 어, 수면의 지속성이나 깊이, 숙면 등을 포함한 수면의 질적인 측면이 공격성을 감소시키고 정서조절능력을 향상시키는 것 으로 보고하였다.

종합하면, 수면은 사회적 행동 뿐 아니라 인지적 조절능 력인 실행기능에도 영향을 미치는 것으로 최근의 연구들은 보고하고 있다. 선행연구들은 또한 실행기능과 사회적 행 동 간 관련성도 살펴보고 있는데, 이러한 연구들은 이전 시 기와 비교하여 유아기에 실행기능과 사회적 행동 간 관련성 이 더욱 명확해지는 것으로 보고하고 있다. 실행기능이 낮 은 유아는 공격성이나 과잉행동과 같은 외현화 문제행동 (Espy, Sheffield, Wiebe, Clark, \& Moehr, 2011; Hughes \& Ensor, 2008; Raaijmakers et al., 2008)과 불안/우울, 위축과 같은 내 면화 문제행동(Hughes \& Ensor, 2008; Rhoades, Greenberg, \& Domitrovich, 2009)을 더 보였으며, 친사회적 행동(Kong \& $\operatorname{Lim}, 2013)$ 은 덜 보였다. 또한 실행기능 수준이 높은 유아는
또래 간 협력적 상호작용 상황에서 경쟁적인 행동을 덜 보였 다(Huyder \& Nilsen, 2012). 실행기능을 작업기억이나 억제 통제와 같은 인지적 실행기능(cool executive function)과 정서 나 동기가 관련된 만족지연능력과 같은 정의적 실행기능(hot executive function)으로 구분하여 문제행동에 미치는 영향을 살펴본 연구에서는 인지적 실행기능보다 정의적 실행기능 이 외현화 및 내면화 문제행동과 친사회적 행동과 더 큰 관련 을 보이는 것으로 보고하였다(Kim, Nordling, Yoon, Boldt, \& Kochanska, 2013).

지금까지 살펴본 것처럼 실행기능은 수면에 의해 영향을 받을 뿐 아니라, 사회적 행동에 영향을 미치는 변인으로 확인 되었다. 즉, 수면과 사회적 행동은 인지적 기능의 지표라 할 수 있는 실행기능과의 관련성을 공유하며, 수면문제를 더 보이는 경우 낮은 수준의 실행기능을 보이고, 실행기능이 낮은 경우 높은 수준의 문제행동을 보이고 친사회적 행동은 덜 보이는 것으로 보고되고 있다. 이를 통해 수면이 사회적 행동에 영향 을 미치는 과정에서 실행기능이 매개적 역할을 담당할 것으로 가정해 볼 수 있다. 비록 유아의 수면이 사회적 행동에 미치는 영향을 실행기능이 매개하는지 여부에 대해 살펴본 연구는 나 타나고 있지 않지만, 영유아기 수면, 실행기능 및 문제행동 간 관련성을 살펴본 연구(Sadeh et al., 2015)와 유아의 개인적 특 성인 기질이 문제행동과 친사회적 행동에 미치는 영향이 정의 적 실행기능(Kong \& Lim, 2012a)과 인지적 실행기능(Kong \& $\mathrm{Lim}, 2012 \mathrm{~b})$ 에 의해 매개되는지 살펴본 연구들이 일부 보고되 고 있다. 본 연구에서는 이러한 연구들에 근거하여 유아의 수 면문제, 실행기능 및 사회적 행동 간의 관계를 살펴보고, 유아 의 수면문제가 사회적 행동에 미치는 영향을 실행기능이 매개 하는지 탐색해 보았다.

한편, 유아를 대상으로 한 선행연구들은 대체로 수면문제 (Vaughn et al., 2015; Whalen et al., 2017; Yokomaku et al., 2008) 와 실행기능(Hala, Hug, \& Henderson, 2003; Hughes \& Ensor, 2008; Park \& Lee, 2013)에서 성차를 발견하지 못하였다. 반 면 문제행동과 친사회적 행동의 경우 남아가 외현화 문제행 동(Basten et al., 2016; Hay, 2007)을, 여아가 내면화 문제행동 (Chaplin \& Aldao, 2013)과 친사회적 행동(Doh, Shin, Kim, Park, \& Na, 2012; Girard, Pingault, Doyle, Falissard, \& Tremblay, 2017)을 더 많이 보이는 것으로 보고되고 있다. 변인들 간 관 계에서 성차를 살펴본 연구는 비록 소수에 불과하지만, 이러 한 연구들(Espy et al., 2011; Hughes \& Ensor, 2008)에서는 수면 문제와 문제행동 간 상관이 남아와 여아에게 유사하게 나타나 는 것으로 보고하였다. 따라서 본 연구에서는 변인들 간 관계 
및 매개효과를 살펴보기에 앞서, 각 변인들에서의 성차 및 각 변인들 간 관계에서 성차가 있는지 확인해 보았다.

요약하면, 본 연구에서는 신체, 인지, 사회정서의 모든 영역 에 영향을 미치는 변인으로 최근 주목받고 있는 수면에 초점 을 두어, 국내 유아의 수면문제가 인지적, 행동적 기능에서의 개인차와 어떠한 관련이 있는지 살펴보았다. 수면문제, 실행 기능 및 사회적 행동의 경우 유아기에 특별한 중요성을 가지 고 있는 변인임에도 불구하고, 유아기를 대상으로 한 수면문 제와 실행기능 간의 관련성, 그리고 수면문제가 사회적 행동 에 미치는 영향에서 실행기능의 매개적 역할을 탐색한 연구들 은 국내외 모두에서 나타나고 있지 않다. 따라서 본 연구를 통 해, 기존 수면 연구의 영역을 확장하고, 이를 통해 유아기 건강 한 발달을 도모하는 데 있어 올바른 수면습관 형성의 중요성 을 환기하고자 하였다. 본 연구의 연구문제와 연구모형(Figure 1)은 다음과 같다.

\section{연구문제 1}

유아의 수면문제, 실행기능 및 사회적 행동 간의 관계는 어떠 한가?

\section{연구문제 2}

유아의 수면문제가 사회적 행동에 미치는 영향을 실행기능이 매개하는가?

\section{연구방법}

\section{연구대상}

본 연구는 만 3-5세 유아 304명을 대상으로 실시되었으며, 자 료는 어머니 보고를 통하여 수집되었다. 만 3-5세 유아를 연

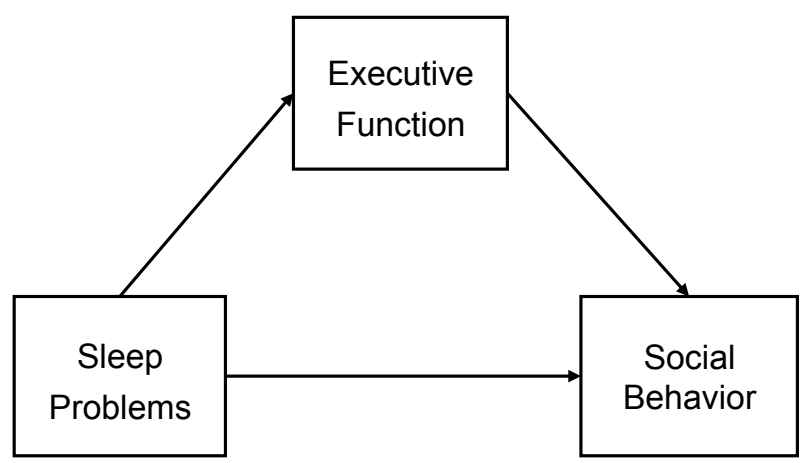

Figure 1. The hypothesized model.
구대상으로 선정한 이유는, 이 시기가 영아기의 불안정한 수 면패턴에서 벗어나 안정적이고 사회적인 수면이 형성되는 중 요한 발달적 전환기일뿐 아니라(Jenni et al., 2007), 실행기능 과 사회적 행동에서의 발달적 변화 또한 나타나는 시기이기 때문이다(Anderson, 2002; Basten et al., 2016; Zelazo \& Müller, 2002).

연구대상의 사회인구학적 특성을 간략히 살펴보면, 남아 가 159 명 (52.30\%), 여아가 143 명(47.04\%)으로 남아가 조금 더 많았다. 연령은 만 3세가 146명(48.03\%), 만 4세가 91명 (29.93\%), 만 5세가 61명(20.67\%)으로 만 3세가 가장 많았다. 부모의 연령은 아버지와 어머니 모두 35-39세가 각각 151명 (49.67\%)과 150명(49.34\%)으로 가장 많았고, 30-34세가 각각 66명(21.71\%)과 104 명(34.21\%)으로 그 뒤를 이었다. 부모의 교육수준은 아버지와 어머니 모두 대학교 졸업이 각각 196명 (64.47\%)과 181명(59.64\%)으로 가장 많았고, 그 다음이 대학 원 이상으로 아버지는 62명(20.39\%), 어머니는 69명(22.70\%) 이었다. 부모의 직업은 아버지의 경우 회사원 및 공무원이 180 명(59.21\%)으로 가장 많았고, 전문직이 44명(14.47\%), 자 영업자가 31 명 $(10.20 \%)$ 순이었다. 어머니의 경우 전업주부 가 157명(51.64\%)으로 가장 많았고, 회사원 및 공무원이 63명 (20.72\%), 전문직이 37명(12.17\%)이었다.

\section{연구도구}

\section{수면문제}

유아의 수면문제를 측정하기 위하여 Owens, Spirito와 McGuinn (2000)의 수면 습관 질문지(The Children's Sleep Habits Questionnaire [CSHQ])를 Y. Kim과 Lee (2011)가 번안, 수정 한 척도를 사용하였다. 수면 습관 질문지는 부모가 지각하는 주관적인 수면문제를 기록하도록 되어 있으며, 8개 영역으로 구성되어 있다. 각 영역의 예를 살펴보면, 수면시간(3문항)은 “너무 많이 잔다.”, 취침시간 저항(6문항)은 “취침시간에 발버 둥친다.”, 수면 불안(4문항)은 "어두운 곳에서 자는 것을 무서 워한다.”, 수면착수 지연(1문항)은 “잠자리에 든 지 20분 이내 에 잠든다.”, 밤 동안에 깨기(3문항)는 "밤에 두 번 이상 깬다.”, 병리적 수면행동(7문항)은 “잠자면서 말을 한다.”, 수면호흡장 애(3문항)는 “코를 크게 곤다.", 주간졸림증(8문항)은 "일어나 서 정신을 차리는 데 오랜 시간이 걸린다.” 등이 있다.

각 문항은 대개 그렇다(주평균 5-7일), 가끔 그렇다(주평균 2-4일), 거의 그렇지 않다(주평균 0-1일)의 3점 Likert식 척도 
로 응답되었으며, 점수가 높을수록 수면문제를 더 보이는 것 을 의미하도록 일부 방향성이 다른 문항을 역코딩하였다. 본 연구에서는 수면문제의 각 하위요인의 영향력보다 전반적인 수면문제의 영향을 살펴보기 위하여 전체 문항의 평균을 산 출하여 분석에 사용하였다. 수면 습관 질문지에 포함된 문항 은 총 35문항이지만, 두 문항(“부모가 같은 방에 있어야 잠이 든다.”, “혼자 잠자는 것을 무서워한다.”)이 '취침시간 저항'과 ‘수면 불안'에 중복되어 포함되기 때문에 수면문제 전체 평균 을 산출하는 데에는 33문항이 사용된다(Owens et al., 2000). 본 연구에서 수면문제를 분석하기 위해 전체 문항을 사용하는 근 거로, Owens 등(2000)의 연구에서 전체 문항을 사용하였을 때 수면문제를 경험하고 있는 집단을 구분하는 데 문제가 없었으 며, 전체 문항으로 산출한 내적합치도(Cronbach's $\alpha$ )가 .71로 나타나 각 문항이 전체 수면문제를 구성하는 하위 문항으로 잘 기능하였다는 점을 들 수 있다. 또한 본 척도를 사용한 여러 선행연구들(El-Sheikh, Buckhalt, Mize, \& Acebo, 2006; Gregory, Rijsdijk, Lau, Dahl, \& Eley, 2009; Hoffman et al., 2008)에서도 단일 요인 사용에 문제가 없음을 보고하였다는 점 또한 이러 한 결정을 뒷받침하였다.

\section{실행기능}

유아의 실행기능은 Gioia, Isquith, Guy와 Kenworthy (2000) 가 개발한 5-18세용 행동 평정 척도를 Isquith, Gioia와 Espy (2004)가 유아용으로 타당화한 실행기능 행동 평정 척도-유 아용(Behavior Rating Inventory of Executive Function-Preschool version [BRIEF-P])을 Seo와 Park (2011)이 번안한 척도를 사용 하여 측정하였다. 본 척도는 5 개의 하위요인으로 구성되며, 감 정조절(10문항)은 “너무 쉽게 화를 낸다.”, 작업기억(17문항) 은 “두 가지 일을 주면 한 가지만 기억한다.", 억제(16문항)는 "지시를 해도 행동을 억제하는 데 문제가 있다.", 전환(10문항) 은 “새로운 상황에 접하면 혼란스러워 한다.”, 계획 및 조직(10 문항)은 "문제해결을 위한 어려운 과제를 수행할 때 대안을 생 각해 내는 것을 어려워한다." 등이 있다.

각 문항은 5점 Likert식 척도로 측정하였으며, BRIEF-P의 문항들의 경우 점수가 높을수록 실행기능의 수준이 낮은 것으 로 서술되어 있기 때문에, 각 하위요인의 점수가 높을수록 실 행기능 수준이 높도록 모든 문항을 역채점하였다. 각 하위요 인의 내적합치도(Cronbach's $\alpha$ )는 감정조절 .88, 작업기억 .93, 억제 .91 , 전환 .84 , 계획 및 조직 .83 이었다.

\section{사회적 행동}

유아의 사회적 행동은 Crick, Casas와 Mosher (1997)의 유아기 사회적 행동 척도(Preschool Social Behavior Scale [PSBS])를 M.J. Kim (2008)이 번안, 수정한 척도를 사용하여 측정하였다. 본 척도는 외현적 공격성, 관계적 공격성, 우울 감정, 그리고 친사 회적 행동의 4 개 하위요인으로 구성되어 있다. 각 하위요인의 문항의 예로는 외현적 공격성(6문항)은 "다른 아이들을 밀치 거나 떠민다.”, 관계적 공격성(6문항)은 "어떤 아이에게 화가 나면, 그 아이가 놀이집단에 들어오지 못하게 한다.”, 우울 감 정(3문항)은 “슬퍼 보인다.", 친사회적 행동(4문항)은 "다른 아 이들을 잘 돕는다." 등이 있다.

각 문항은 4점 Likert식 척도로 응답되었으며, 각 하위요인 의 점수가 높을수록 외현적 공격성과 관계적 공격성을 많이 나타내고, 우울 수준이 높으며, 친사회적 행동을 많이 보이는 것을 의미한다. 각 하위요인별 내적합치도(Cronbach's $\alpha$ )는 외 현적 공격성 .87 , 관계적 공격성 .86 , 우울 감정 .84 , 친사회적 행동 .84 이었다.

\section{연구절차 및 자료분석}

본 연구의 자료수집은 $\mathrm{E}$ 대학교 생명윤리위원회의 승인(IRB NO. 130-13) 후 실시되었다. 먼저 인터넷 육아 커뮤니티에 모 집문건을 공지한 후 자발적으로 연구에 참여 신청을 한 어머 니들을 대상으로 연구에 대해 설명하였다. 연구설명 후에도 참여에 동의한 분들에게 질문지와 동의서를 355 부 발송하였 으며 우편으로 308 부를 회수하였다. 이 중 불충분하게 응답된 4 부를 제외하고 총 304 부가 연구에 사용되었다. 연구참여자 에게는 모바일 문화상품권 1만원을 지급하였다.

수집된 자료는 SPSS 23.0 (IBM Co., Armonk, NY) 프로그램 을 이용하여 분석하였다. 본 분석에 앞서 예비분석으로 연구 의 주요 변인들, 즉 유아의 수면문제, 실행기능 및 사회적 행동 이 유아의 성별에 따라 차이가 있는지 살펴보기 위하여 $t$ 검정 을 실시하였다. 본 분석에서는, 유아의 수면문제, 실행기능 및 사회적 행동 간의 관계를 살펴보기 위해 Pearson의 적률상관계 수를 산출하였다. 또한 유아의 수면문제와 사회적 행동 간의 관계에서 유아의 실행기능의 매개적 역할을 검증하기 위하여 Baron과 Kenny (1986)가 제안한 3단계 모형 접근법을 사용하 여 단순회귀분석과 중다회귀분석을 실시하였으며, Sobel test 를 사용하여 간접효과의 통계적 유의성을 검증하였다. 


\section{연구결과}

\section{예비분석}

본 분석에 앞서 유아의 수면문제, 실행기능 및 사회적 행동이 유아의 성별에 따라 차이가 있는지 살펴보기 위하여 $t$ 검정을 실시하였다. 그 결과, 수면문제에서는 유의한 성차가 발견되 지 않았으나, 실행기능 중 작업기억 $(t=-2.81, p<.01)$, 억제 $(t=$ $-3.65, p<.001)$, 계획 및 조직 $(t=-2.39, p<.05)$ 에서는 성차가 나타났다. 구체적으로, 작업기억(여: $M=4.28, S D=0.51$; 남: $M=4.11 S D=0.55)$, 억제(여: $M=4.27, S D=0.53$; 남: $M=4.02$ $S D=0.64)$, 계획 및 조직(여: $M=4.15, S D=0.50 ;$ 남: $M=4.01$ $S D=0.53)$ 모두에서 여아가 남아보다 높은 수준의 실행기능 을 보였다. 사회적 행동의 경우에는 남아 $(M=1.38, S D=0.49)$ 가 여아 $(M=1.17, S D=0.30)$ 보다 외현적 공격성 $(t=4.45, p<$ .001)을 더 많이 보였으나, 관계적 공격성과 우울 감정에서는 남녀 간 성차가 유의하지 않았다. 마지막으로, 여아 $(M=3.25$, $S D=0.45)$ 가 남아 $(M=3.05, S D=0.49)$ 보다 친사회적 행동 $(t=$ $-3.69, p<.001)$ 을 더 많이 보였다.

\section{유아의 수면문제, 실행기능 및 사회적 행동 간의 관계}

유아의 수면문제, 실행기능 및 사회적 행동 간의 관계를 살 펴보기 위해 Pearson의 적률상관계수를 산출하였다(Table 1). 먼저 유아의 수면문제와 사회적 행동 간의 관계를 살펴본 결 과, 수면문제는 외현적 공격성과는 정적 상관 $(r=.14, p<.05)$ 을, 친사회적 행동과는 부적 상관 $(r=-.13, p<.05)$ 을 보여, 유 아가 수면문제를 더 가지고 있을수록 외현적 공격성은 더 많 이 보이고 친사회적 행동은 더 적게 나타내었다. 하지만 수면 문제는 관계적 공격성 및 우울 감정과는 유의한 상관을 보이 지 않았다. 다음으로, 유아의 수면문제와 실행기능의 모든 하 위요인들은 유의한 부적 상관관계( $r s=-.20 \sim-.26, p<.01$ 또는 $p<.001)$ 를 나타내어, 유아가 수면문제를 더 경험할수록 낮은 수준의 실행기능을 보였다. 마지막으로, 유아의 실행기능과 사회적 행동 간의 상관관계를 살펴본 결과, 유아의 실행기능 의 모든 하위요인들은 사회적 행동의 모든 하위요인들과 유의 한 상관을 가지고 있었다. 구체적으로, 유아의 외현적 공격성 $(r s=-.21 \sim-.53, p<.001)$, 관계적 공격성 $(r s=-.17 \sim-.37, p<.01$

Table 1

Correlations Among Preschoolers' Sleep Problems, Executive Function and Social Behavior

\begin{tabular}{lllllllllllll} 
Variables & 1 & 2 & 3 & 4 & 5 & 6 & 7 & 8 & 9 & 10 \\
\hline
\end{tabular}

Sleep problems

1. Sleep problems

Executive function

2. Emotional control

3. Working memory

4. Inhibition

5. Shift

6. Planning/Organizing

$\begin{array}{lllll}-.26^{* * *} & - & & & \\ -.22^{* * *} & .62^{* * *} & - & & \\ -.20^{* *} & .68^{* * *} & .76^{* * *} & - & \\ -.20^{* *} & .61^{* * *} & .52^{* * *} & .39^{* * *} & - \\ -.25^{* * *} & .59^{* * *} & .85^{* * *} & .70^{* * *} & .53^{* * *}\end{array}$

Social behavior

\begin{tabular}{|c|c|c|c|c|c|c|c|c|c|c|}
\hline 7. Overt aggression & $.14^{*}$ & $-.48^{* * *}$ & $-.38^{* * *}$ & $-.53^{* * *}$ & $-.21^{* * *}$ & $-.35^{* * *}$ & - & & & \\
\hline 8. Relational aggression & .11 & $-.37^{* * *}$ & $-.29^{* * *}$ & $-.35^{* * *}$ & $-.17^{* *}$ & $-.28^{* * *}$ & $.59^{* * *}$ & - & & \\
\hline 9. Depressed affect & .10 & $-.30^{* * *}$ & $-.32^{* * *}$ & $-.24^{* * *}$ & $-.36^{* * *}$ & $-.29^{* * *}$ & $-.18^{* *}$ & $.17^{* *}$ & - & \\
\hline$M$ & 1.52 & 3.92 & 4.20 & 4.14 & 3.96 & 4.08 & 1.29 & 1.29 & 1.27 & 3.14 \\
\hline$S D$ & 0.19 & 0.64 & 0.54 & 0.60 & 0.61 & 0.52 & 0.43 & 0.43 & 0.40 & 0.48 \\
\hline
\end{tabular}

Note. $N=304$.

${ }^{*} p<.05 .{ }^{* *} p<.01 .{ }^{* * *} p<.001$. 
또는 $p<.001)$ 과 우울 감정 $(r s=-.24 \sim-.36, p<.001)$ 은 실행기 능의 모든 하위요인들과 유의한 부적 상관을, 유아의 친사회 적 행동은 실행기능의 모든 하위요인들과 유의한 정적 상관(rs $=.34 \sim .47, p<.001)$ 을 가지고 있었다. 즉, 유아의 실행기능 수 준이 높을수록 유아는 외현적 공격성, 관계적 공격성과 우울 감정은 적게 보였으며, 친사회적 행동을 더 많이 보였다.

앞서 예비분석에서 실행기능과 사회적 행동의 일부 하위요 인들에서 유의한 성차가 나타나, 유아의 수면문제, 실행기능 및 사회적 행동 간 상관에서도 성차가 나타나는지 살펴보기 위해 남아와 여아 각각을 대상으로 상관관계 분석을 실시하였 다. 남아의 상관계수와 여아의 상관계수가 유의하게 다른지 살펴보기 위해 Fisher의 $z$ 변형을 실시한 결과, 전체 상관계수의 $16 \%(45$ 쌍 중 7쌍)에서만 유의한 차이가 나타나 추후분석에서 는 성별을 통제하지 않았다. 한편, 실행기능의 하위요인들 간 상관을 살펴본 결과, 그 상관은 .39 .85로 높았으며, 실행기 능의 하위요인들은 수면문제 및 사회적 행동과 유사한 상관을 보였다. 따라서 실행기능의 하위요인들이 하나의 요인에 적재 되는지 살펴보기 위해 요인분석을 실시하였다. 그 결과, 하나 의 요인이 추출되었으며, 이 요인은 전체의 $70.48 \%$ 를 설명하 였다. 따라서 실행기능의 총점을 산출하여 추후분석에 사용하 였다.

\section{유아의 수면문제와 사회적 행동 간의 관계에 서 실행기능의 매개적 역할}

유아의 수면문제와 사회적 행동 간의 관계에서 실행기능이 매개적 역할을 담당하는지 살펴보기 위하여 Baron과 Kenny (1986)가 제안한 3단계 모형 접근법을 사용하였다. Baron과 Kenny (1986)의 3 단계 모형의 1 단계에서는 독립변인이 종속
변인에 미치는 영향(모형 1)을, 2단계에서는 독립변인이 매개 변인에 미치는 영향(모형 2)을, 그리고 3단계에서는 독립변인 과 매개변인을 함께 투입하여 종속변인에 미치는 영향(모형 3)을 살펴본다. 매개효과가 성립하기 위해서는 3 단계에서 매 개변인이 종속변인에 유의한 영향을 미쳐야 하며, 1 단계에서 유의하였던 독립변인의 효과가 3 단계에서 감소하거나(부분 매개), 더 이상 유의하지 않아야 한다(완전매개). 이에 근거하 여, 본 연구에서는 1 단계에서는 유아의 수면문제가 사회적 행 동에 미치는 영향을, 2 단계에서는 유아의 수면문제가 실행기 능에 미치는 영향을, 그리고 마지막 3단계에서는 유아의 수면 문제와 실행기능을 함께 투입하여 사회적 행동에 미치는 영 향을 살펴보았다. 사회적 행동 중 관계적 공격성과 우울 감정 은 수면문제와 유의한 상관을 보이지 않아, 외현적 공격성과 친사회적 행동만을 대상으로 매개분석을 실시하였다. DurbinWatson값은 1.91 2.08로 오차 간 자기 상관은 나타나지 않았 으며, 중다회귀분석 시 분산팽창계수(variance inflation factor) 와 공차한계(tolerance)도 각각 1.07 과 .93으로 다중공선성의 위험은 없었다. 각각의 결과를 구체적으로 서술하면 다음과 같다.

첫째, 유아의 수면문제와 외현적 공격성 간의 관계에서 유 아의 실행기능의 매개적 역할을 살펴본 결과(Table 2, Figure 2), 모형 1 과 2 에서 유아의 수면문제는 종속변인인 외현적 공 격성 $(\beta=.14, p<.05)$ 과 매개변인인 실행기능 $(\beta=-.26, p<$ .001)에 유의한 영향을 미쳤다. 모형 3에서 수면문제와 실행기 능을 함께 투입한 결과, 실행기능은 외현적 공격성에 유의한 영향을 미쳤으나 $(\beta=-.47, p<.001)$, 수면문제가 외현적 공격 성에 미치는 영향은 더 이상 유의하지 않았다 $(\beta=.14, p<.05$ $\rightarrow \beta=.01, n s)$. 즉, 유아의 실행기능은 유아의 수면문제와 외 현적 공격성 간의 관계를 완전매개 하였다. Sobel test를 실시한

Table 2

Preschoolers' Executive Function as a Mediator of the Relationship Between Sleep Problems and Overt Aggression

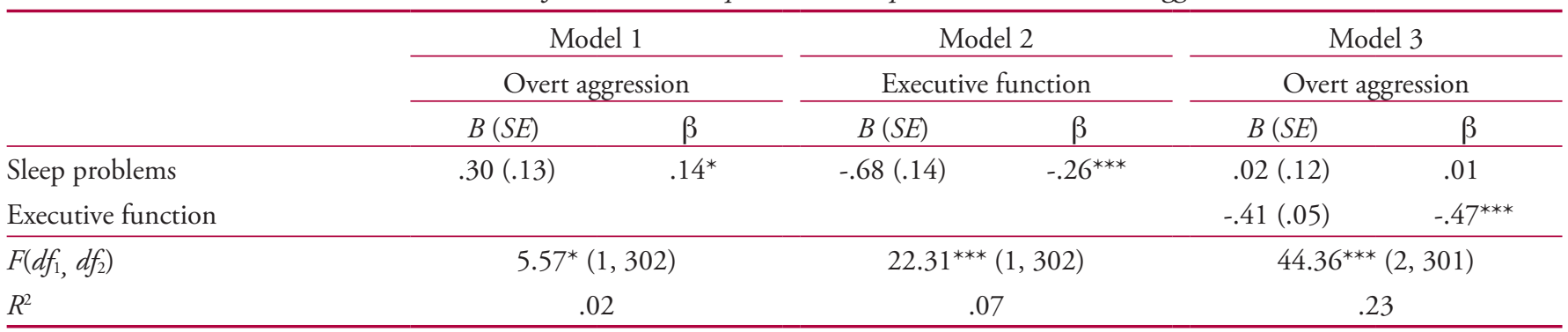

Note. $N=304$.

${ }^{*} p<.05 .{ }^{* * *} p<.001$. 
결과 이러한 매개효과는 통계적으로 유의하였다 $(z=4.18, p<$ .001).

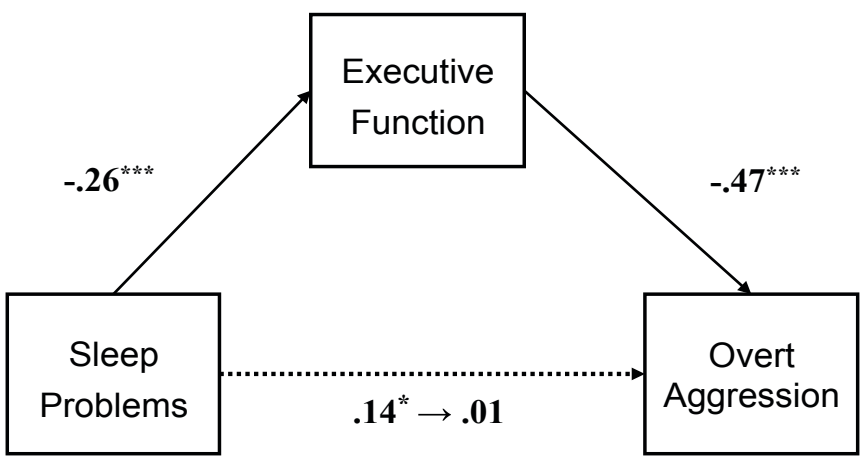

Figure 2. Preschoolers' executive function as a mediator of the relationship between sleep problems and overt aggression. Standardized coefficients are given.

${ }^{*} p<.05 .{ }^{* * *} p<.001$.

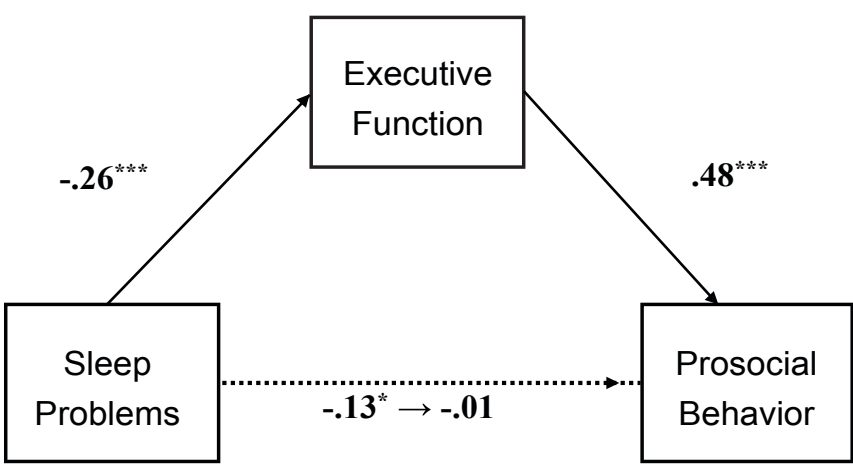

Figure 3. Preschoolers' executive function as a mediator of the relationship between sleep problems and prosocial behavior. Standardized coefficients are given.

${ }^{*} p<.05 .{ }^{* * *} p<.001$.
둘째, 유아의 수면문제와 친사회적 행동 간의 관계에서 유 아의 실행기능의 매개적 역할을 살펴보았다(Table 3, Figure 3). 그 결과, 모형 1 과 2 에서 유아의 수면문제는 유아의 친사회적 행동 $(\beta=-.13, p<.05)$ 과 실행기능 $(\beta=-.26 p<.001)$ 에 유의한 영향을 미쳤다. 모형 3에서 유아의 실행기능과 친사회적 행동 을 함께 투입하였을 때, 유아의 실행기능은 친사회적 행동에 유의한 영향을 미쳤으나 $(\beta=.48, p<.001)$, 유아의 수면문제는 친사회적 행동에 더 이상 영향을 미치지 않았다 $(\beta=-.13, p<$ $.05 \rightarrow \beta=-.01, n s)$. 즉, 유아의 실행기능은 유아의 수면문제와 친사회적 행동 간의 관계를 완전매개 하였으며, 이는 통계적 으로 유의하였다 $(z=-4.32, p<.001)$.

\section{논의 및 결론}

본 연구는 만 3-5세 유아의 수면문제, 실행기능 및 사회적 행 동 간의 관계를 살펴보고, 수면문제와 실행기능(e.g., Bernier et al., 2013), 실행기능과 사회적 행동(e.g., Hughes \& Ensor, 2008; B. Y. Kim, 2015) 간 관련성을 보고한 선행연구들에 근거하여, 유아의 수면문제와 사회적 행동 간의 관계에서 실행기능의 매 개적 역할을 탐색하였다. 본 연구의 주요 결과를 요약하고 논 의하면 다음과 같다.

첫째, 유아의 수면문제와 사회적 행동 간의 관계와 관련하 여, 유아의 수면문제는 사회적 행동의 네 가지 하위요인들 가 운데 외현적 공격성과는 유의한 정적 상관을, 친사회적 행동 과는 유의한 부적 상관을 보였다. 즉, 수면문제를 경험하는 유 아들은 외현적 공격성을 더 많이 보이고 친사회적 행동은 덜 보이는 것으로 나타났다. 본 연구에서 발견한 유아의 수면문 제와 외현적 공격성 간의 정적 관련성은 수면의 만족도나 규

Table 3

Preschoolers' Executive Function as a Mediator of the Relationship Between Sleep Problems and Prosocial Behavior

\begin{tabular}{|c|c|c|c|c|c|c|}
\hline & \multicolumn{2}{|c|}{ Model 1} & \multicolumn{2}{|c|}{ Model 2} & \multicolumn{2}{|c|}{ Model 3} \\
\hline & $B(S E)$ & $\beta$ & $B(S E)$ & $\beta$ & $B(S E)$ & $\beta$ \\
\hline Sleep problems & $-.34(.14)$ & $-.13^{*}$ & $-.68(.14)$ & $-.26^{* * *}$ & $-.02(.13)$ & -.01 \\
\hline Executive function & & & & & $.47(.05)$ & $.48^{* * *}$ \\
\hline$R^{2}$ & \multicolumn{2}{|c|}{.02} & \multicolumn{2}{|c|}{.07} & \multicolumn{2}{|c|}{.23} \\
\hline
\end{tabular}

Note. $N=304$.

${ }^{*} p<.05 .{ }^{* * *} p<.001$. 
칙성, 지속성 등과 같은 수면의 질이 낮은 유아가 높은 신체 적 공격성을 보인다는 연구결과(You \& Cho, 2014)나 수면시 간이 짧거나 숙면을 취하지 못하는 유아가 외현화 문제행동 을 더 많이 나타낸다는 연구결과들(Hwang, 2016; Y.-H. Kim, 2015)과 유사하다. 또한, 본 연구에서 밝힌 유아의 수면문제와 친사회적 행동 간의 부적 관련성은 야간 수면시간이 적은 유 아가 또래수용성과 사회적 참여가 낮다는 연구결과(Vaughn et al., 2015)나 초등학교에 입학하는 아동을 대상으로 잠이 드는 데 어려움을 경험하는 아동이 낮은 친사회적 행동을 보인다는 연구결과(Lehmkuhl, Wiater, Mitschke, \& Fricke-Oerkermann, 2008)와 유사하다. 이러한 결과들을 통해 충분한 시간 동안 효 율적인 수면을 취하지 못하는 유아가 짜증을 내거나 쉽게 흥 분하는 것과 같이 정서조절에서의 문제를 겪을 수 있으며(You $\& \mathrm{Cho}, 2014)$, 이로 인해 또래와의 관계에서 신체적 공격성을 보이거나 친사회적 행동을 덜 보이는 등 또래와 긍정적으로 상호작용하는 데 어려움을 경험할 수 있으리라 사료된다. 유 아의 수면문제와 외현적 공격성을 포함한 문제행동 간의 관계 를 다룬 선행연구들에 비해, 유아의 수면문제와 친사회적 행 동 간의 관계를 살펴본 선행연구들은 상대적으로 드물다. 따 라서 추후 수면문제가 긍정적인 사회적 행동에 미치는 영향에 대해 계속해서 재검증해볼 필요가 있다.

한편, 본 연구에서는 유아의 수면문제와 관계적 공격성 및 우울 감정 간에 유의한 상관이 발견되지 않았다. 특히 유아의 수면문제가 외현적 공격성과는 관련이 있는 반면, 관계적 공 격성과는 관련이 없었다는 점에 주목할 만하다. 수면문제와 공격성 간의 관계를 다룬 선행연구들을 살펴보면, 본 연구와 같이 외현적 공격성과 관계적 공격성으로 구분하기보다 공격 성을 외현화 문제행동이라는 커다란 범주 안에 포함시켜 살펴 본 경우가 많았다(Hwang, 2016; Y.-H. Kim, 2015; Reid, Hong, \& Wade, 2009). 이에 유아의 수면문제와 관계적 공격성 간의 관련성을 발견하지 못한 본 연구결과를 해석하기가 쉽지는 않 으나, 외현적 공격성과 달리 관계적 공격성은 은밀한 방식으 로 나타난다는 특성에 근거해볼 때(Crick, 1995), 적절한 수면 을 취하지 못한 유아는 부정적 정서를 또래와 놀아주지 않거 나 놀이집단에 들어오지 못하도록 하는 것과 같이 간접적인 방식으로 드러내기보다는 때리거나 밀치는 것과 같이 보다 직 접적인 방식으로 표출함을 알 수 있다. 이러한 결과는 수면문 제와 언어능력 그리고 언어능력과 관계적 공격성 간의 관련성 을 보고한 선행연구들에 비추어 조심스럽게 해석해볼 수 있 다. 즉, 영유아기에 수면문제가 있는 경우 낮은 언어능력을 보 인다는 연구결과(Touchette et al., 2007)나 관계적 공격성을 보
이는 유아는 신체적 공격성을 보이는 유아보다 표현 언어 수 준이 유의하게 높다는 연구결과(Shin, 2008)로 미루어볼 때, 수면에서 문제를 경험하는 유아가 또래와의 갈등 상황에서 낮 은 언어능력으로 인해 관계적 공격성보다는 외현적 공격성을 나타낼 수도 있을 것이다. 본 연구의 결과는 유아의 수면문제 가 공격성의 유형에 따라 다른 영향을 줄 수 있음을 시사하며, 후속 연구에서도 공격성의 유형을 구분하여 살펴봄으로써 그 영향력을 명확히 확인할 필요가 있음을 제안한다. 또한, 후속 연구에서는 언어능력을 함께 고려하여, 이를 통제한 후에도 수면문제가 공격성의 유형에 미치는 영향에 차이가 있는지를 확인해보는 것도 흥미로울 것이다.

본 연구에서는 유아의 수면문제와 우울 감정 간에도 관련 이 없는 것으로 나타났는데, 이는 두 변인 간의 관련성을 보고 한 선행연구들의 결과와 일치하지 않는다. 예를 들어, 선행연 구들에서는 수면시간이 짧은 유아가 우울과 불안을 더 보였 으며(Hale, Berger, LeBourgeois, \& Brooks-Gunn, 2011), 수면문 제를 많이 경험하는 2-3세 유아가 내재화 문제행동을 더 많이 나타내었다(Reid et al., 2009). 이러한 차이는 선행연구들은 우 울과 불안을 함께 측정하거나 우울을 내재화 문제행동 안에 포함시켜 다룬 반면, 본 연구에서는 우울 감정만을 측정하였 기 때문일 가능성이 있다. 뿐만 아니라 수면과 가정의 사회경 제적 지위(El-Sheikh, Kelly, Buckhalt, \& Hinnant, 2010) 및 기질 (Cremone et al., 2017)이 상호작용하여 내면화 문제행동에 영 향을 미치는 것으로 보고한 선행연구들에 근거해볼 때, 유아 의 수면문제와 우울 감정 간의 관계에 중재변인으로 작용하는 제 3의 변인이 존재할 가능성도 고려해볼 수 있다. 따라서 추 후 연구에서는 유아의 수면문제와 우울 감정 간의 관계를 살 펴보는 데 있어 가정의 사회경제적 지위나 유아의 기질 등을 함께 다루어보는 것이 필요하다.

둘째, 유아의 수면문제와 실행기능 간의 관계와 관련하여, 유아의 수면문제는 실행기능의 다섯 가지 하위요인들 모두와 유의한 부적 상관을 보였다. 즉, 수면습관에 문제가 있는 유아 들은 감정조절이나 작업기억, 억제, 전환, 계획 및 조직화 등과 같은 실행기능이 모두 낮은 것으로 나타났다. 수면문제와 낮 은 실행기능 간의 관련성은 수면이 전두엽의 발달에 영향을 미치고, 실행기능 또한 전두엽의 통제 아래 있기 때문일 수 있 다(Jones \& Harrison, 2001). 본 연구의 결과는 유아의 수면의 양과 질이 인지발달에 영향을 미침을 보고한 국내외 선행연구 들과 동일한 맥락이다. 구체적으로, 수면의 양, 즉 야간 수면시 간의 양은 유아의 인지적 능력과 정적 상관이 있는 것으로 보 고되었다(Vaughn et al., 2015). 종단적인 연구에서도 이러한 관 
련성이 밝혀졌는데, 수면시간을 2.5 세부터 6세까지 5차례에 걸쳐 조사한 결과 6 세까지 만성적으로 밤에 10 시간 미만을 자 는 아동과 초기에는 밤에 적게 자다가 41 개월 즈음부터 수면 시간이 증가한 아동은 초등학교 입학 시기 즈음에 실시한 인 지적 과제에서 낮은 성취를 보였다(Touchette et al., 2007). 이 러한 결과는 긍정적인 인지발달을 위해 특히 생애 초기에 10 시간 이상의 충분한 수면시간을 가지는 것이 중요함을 시사 한다. 이와 더불어, 수면의 질의 지표 중 밤에 깨지 않고 잘 자 는지와 관련된 숙면 역시 유아의 인지발달에 정적인 영향을 미쳤다(S. J. Kim, 2015). 본 연구의 결과와 선행연구들의 결과 를 종합해볼 때, 유아의 수면은 실행기능을 비롯한 인지적 능 력에 영향을 미침을 알 수 있다. 앞서 살펴본 것과 같이 유아 를 대상으로 한 선행연구들은 수면과 일반적인 인지적 기능 간의 관련성을 주로 다루고 있지만, Bernier 등(2013)의 연구에 서는 1 세 때 아동의 수면이 그 이후 일반적인 인지적 기능보 다 실행기능과 보다 밀접하게 관련됨을 보고하고 있다. 한편, 12 개월과 3-4세 때 두 차례에 걸쳐 수면을 조사한 종단 연구에 서는 유아기의 수면보다 영아기의 수면이 유아의 실행기능을 더 잘 예측하는 것으로 나타났다(Sadeh et al., 2015). 이러한 연 구결과는 부모가 유아기뿐만 아니라 영아기부터 자녀의 수면 에 관심을 가질 필요가 있음을 시사한다. 이와 함께, Bernier 등 (2013)은 총 수면시간과 함께 총 수면시간 대 야간 수면시간의 비율을 고려함으로써, 1 세 때 총 수면에서 야간 수면의 비율 이 높은 아동이 2 세와 4 세 때 높은 실행기능을 보인 반면, 1 세 때 총 수면시간은 이와 유의한 상관이 없는 것을 발견하였다. 이는 특히 실행기능의 발달과 관련하여 밤 동안에 이루어지는 영유아의 수면이 중요할 수 있음을 강조한다.

셋째, 유아의 실행기능과 사회적 행동 간의 관계와 관련하 여, 유아의 실행기능의 다섯 가지 하위요인들은 사회적 행동 의 네 가지 하위요인들 가운데 외현적 및 관계적 공격성, 우울 감정과는 유의한 부적 상관을 보이고 친사회적 행동과는 유의 한 정적 상관을 보였다. 즉, 감정조절이나 작업기억, 억제, 전 환, 계획 및 조직화 등과 같은 실행기능이 높은 유아들은 외현 적 및 관계적 공격성과 우울 감정을 덜 보이고 친사회적 행동 을 더 많이 보이는 것으로 나타났다. 유아의 실행기능과 외현 적 공격성 간의 부적 관계를 밝힌 본 연구의 결과는 유아를 대 상으로 감정조절, 작업기억, 억제, 계획 및 조직화와 같은 실행 기능의 하위요인들과 적대적 반항 행동 간의 관련성을 보고한 선행연구(Espy et al., 2011)의 결과와 유사하다. 이는 사고와 행 동을 의식적으로 조절하는 인지능력인 실행기능이 외현적 공 격성이 발현되는 것을 통제하는 기능을 담당할 수 있음을 의
미한다. 다시 말해, 유아기에 실행기능의 하위요인들이 발달 하면서(Garon et al., 2008; Zelazo et al., 2003), 실행기능 수준이 높은 유아는 분노나 짜증과 같은 부정적 감정을 표출하는 과 정에서 이를 조절하고 통제함으로써 물건을 부수거나 타인을 때리는 것과 같은 외현적 공격성을 덜 보이는 것으로 해석할 수 있다. 한편, 대부분의 유아는 24-60개월 사이에 신체적 공 격성을 이전보다 덜 보이는 경향이 있는데(Tremblay \& Nagin, 2005), 이 시기가 실행기능의 하위요인들이 급격하게 발달하 는 시기(Garon et al., 2008; Zelazo et al., 2003)와 맞물린다는 점 에서 실행기능의 발달이 신체적 공격성의 감소와 관련될 수 있음을 시사한다. 유아의 실행기능과 외현적 공격성 간의 부 적 관련성에 더해, 본 연구는 유아의 실행기능이 관계적 공격 성과도 부적 관계가 있음을 발견하였다. 유아의 실행기능과 관계적 공격성 간의 관련성을 직접적으로 살펴본 선행연구를 발견하기가 쉽지 않으나, 본 연구결과는 실행기능의 하위요인 들 가운데 하나인 감정조절이나 억제 성향이 낮은 유아가 관 계적 공격성을 더 많이 보인다는 연구결과(Min, 2009)와 유사 한 맥락이다. 추후 유아의 실행기능이 신체적 공격성에 미치 는 영향뿐만 아니라 관계적 공격성에 미치는 영향에 대해서도 연구자들의 관심이 요구된다.

이 외에도 본 연구는 유아의 실행기능과 우울 감정 간의 부 적 관계를 발견하였다. 이는 4 세에서 6 세까지의 실행기능의 발달적 변화를 살펴본 결과 실행기능이 높을수록 6세 때 우울, 걱정, 두려움 등과 같은 정서적 증상을 덜 보인다는 연구결과 (Hughes \& Ensor, 2011)와 일맥상통하며, 인지적 및 정의적 실 행기능이 높은 유아가 우울, 불안, 위축 등을 포함한 내재화 문 제행동을 덜 경험한다는 연구결과(Kong \& Lim, 2013)와 유사 하다. 이러한 결과는 실행기능의 수준이 높을수록 유아가 부 정적 사고나 감정을 잘 조절하고, 이를 긍정적으로 전환하여 우울과 같은 부정적 감정을 덜 느끼는 것으로 이해해볼 수 있 다. 유아의 실행기능은 외현적 및 관계적 공격성, 우울 감정 등 과 같은 문제행동과는 부적 관계가 나타난 반면, 친사회적 행 동과는 정적 관계가 나타났다. 이러한 결과는 유아의 인지억 제, 행동억제 및 작업기억 등의 실행기능이 높을수록 친사회 성이 높다는 선행연구(B. Y. Kim, 2015)의 결과와 일치한다. 즉, 자신의 사고와 감정, 행동을 적절히 조절하고, 주의를 잘 전환하며, 과제를 수행할 때 적절하게 계획하고 조직할 수 있 는 유아는 또래를 돕고 또래와 협동하며 갈등이 발생하더라도 효과적으로 문제를 해결함을 알 수 있다.

넷째, 본 연구에서는 선행연구들을 통해 보고된 유아의 수 면문제, 실행기능 및 사회적 행동 간의 밀접한 관련성을 근거 
로, 유아의 실행기능이 수면문제와 사회적 행동 간의 관계를 매개하는지를 탐색해보았다. 특히 본 연구에서 발견된 유아 의 수면문제와 외현적 공격성 및 친사회적 행동 간의 다소 낮 은 상관(외현적 공격성: $r=.14, p<.05$; 친사회적 행동: $r=-.13$, $p<.05)$ 은 이 변인들 간의 관계에서 매개변인이 존재할 가능 성을 시사하며, 상대적으로 수면문제와 실행기능 $(r=-.26, p<$ .001) 그리고 실행기능과 외현적 공격성 및 친사회적 행동(외 현적 공격성: $r=-.48, p<.001$; 친사회적 행동: $r=.48, p<.001$ ) 간의 높은 상관을 통해 이 변인들 간의 관계에서 실행기능이 매개적 역할을 하리라 예상할 수 있다. 실제로 본 연구에서는 유아의 실행기능이 수면문제와 외현적 공격성 및 친사회적 행 동 간의 관계를 완전매개 하는 것으로 나타났다. 즉, 수면에서 문제를 경험하는 유아는 낮은 실행기능을 보였으며, 이는 외 현적 공격성을 증가시키거나 친사회적 행동을 감소시키는 것 으로 연결되었다. 유아의 수면문제와 외현적 공격성 및 친사 회적 행동 간의 관계에서 실행기능의 매개적 역할을 살펴본 선행연구를 발견하기가 어려워, 본 연구의 결과를 선행연구의 결과와 직접적으로 비교하기는 쉽지 않다. 다만, 본 연구의 결 과는 유아의 수면문제가 주의집중 문제를 야기하고 이는 또래 간 상호작용에서의 어려움으로 이어진다는 결과를 통해 유아 의 수면문제와 또래 상호작용 간의 관계에서 주의집중 문제의 매개적 역할을 밝힌 연구결과(Choi \& Song, 2015)와 다소 유 사하다. 이러한 연구결과들을 통해 유아의 수면문제가 또래와 의 관계에서 보이는 부적절한 사회적 행동으로 나타나는 과정 에서 실행기능이나 주의집중과 같은 자기 자신을 조절하는 능 력이 중요한 역할을 하고 있음을 알 수 있다.

결론적으로 본 연구의 결과는 유아의 수면문제가 실행기능 과 사회적 행동에 미치는 영향력을 발견함으로써, 국내에서 아직까지 연구자들이 관심을 덜 가져온 수면의 중요성을 강 조하고 있다. 구체적으로 본 연구는 유아기의 수면문제가 낮 은 인지적 기능뿐만 아니라 높은 문제행동 및 낮은 친사회적 행동과도 관련됨을 밝혔다. 이러한 결과는 부모가 유아의 건 강한 발달을 위해 충분하고 성숙한 수면을 취할 수 있도록 양 육할 필요가 있음을 시사한다. 특히 한국의 유아가 미국, 영 국, 캐나다 등 서양권의 유아보다 더 늦게 잠자리에 들고 밤에 더 적게 자며 총 수면시간도 더 적다는 연구결과(J. Kim, 2015) 는 우리나라 부모가 유아기 자녀의 수면습관 지도에 더 많은 관심을 가질 필요가 있음을 강조한다. 또한, 어린 유아에게 낮잠이 필수적이기는 하나, 유아의 낮잠이 야간 수면을 방해 할 뿐만 아니라 낮은 인지적 기능과 관련될 수 있으므로(Lam, Mahone, Mason, \& Scharf, 2011), 유아기 자녀를 둔 부모는 유
아가 특히 야간에 방해받지 않고 최적의 수면을 취할 수 있도 록 도와야 할 것이다. 5 세 때 좋은 수면을 보인 경우 14 세가 되 었을 때 자아존중감이나 또래관계 등과 같은 심리사회적 기능 이 더욱 긍정적이었다는 연구결과(Brand et al., 2015)는 유아기 수면이 아동발달에 미치는 장기적 효과를 시사하는 것으로, 이는 유아기 수면습관의 중요성을 더욱 강조한다. 유아의 수 면에 부모-자녀관계의 질과 같은 환경적 요인이 영향을 줄 수 있으므로(Bordeleau, Bernier, \& Carrier, 2012), 부모는 유아기에 바람직한 수면습관을 형성하도록 지도하는 것과 더불어 유아 와 긍정적인 상호작용을 하도록 노력할 필요가 있겠다.

연구의 제한점과 이를 근거로 한 후속 연구를 위한 제언은 다음과 같다. 첫째, 본 연구는 유아의 수면문제, 실행기능 및 사회적 행동 등 모든 연구변인들을 질문지에 의한 어머니 보 고로 측정하였다. 이에 어머니의 주관적 견해가 응답에 포함 되거나 변인들 간의 관계가 실제보다 부풀려졌을 가능성이 있다. 따라서 후속 연구에서는 연구변인들을 보다 객관적으 로 측정할 필요가 있다. 구체적으로 수면의 경우 실제 수면의 양이나 질을 보다 정확하게 측정할 수 있는 수면활동기록기 (actigraph)를 사용하거나(Sadeh, Alster, Urbach, \& Lavie, 1989), 실행기능의 경우 과제를 통한 실험적 절차(Carlson, 2005)로 측정하거나, 사회적 행동의 경우 제 3 자에 의한 객관적인 관 찰을 통해 측정할 수도 있을 것이다. 둘째, 본 연구는 수면문제 라는 단일요인으로 유아의 수면에 대해 살펴봄으로써, 수면 의 구체적인 하위요인들이 실행기능 또는 사회적 행동에 미 치는 영향력을 구분하여 확인하지 못하였다는 점에서 제한점 이 있다. 수면의 양과 질(S. J. Kim, 2015) 또는 총 수면시간과 야간 수면시간(Bernier et al., 2013)이 미치는 영향이 서로 다를 수 있음을 보고한 선행연구들의 결과를 근거로, 후속 연구에 서는 수면을 보다 세부적으로 구분하여 유아의 수면이 발달에 미치는 영향에 대해 보다 심도있게 연구할 필요가 있다. 마지 막으로 본 연구는 유아기를 대상으로 수면문제가 실행기능 및 사회적 행동에 미치는 영향을 살펴보았는데, 후속 연구에서는 영아기나 걸음마기, 학령기와 같이 보다 다양한 연구대상을 통해 수면이 아동의 발달에 미치는 영향을 확인해보는 것도 흥미로울 것이다.

이러한 제한점에도 불구하고, 본 연구는 다음과 같은 의의 를 지닌다. 본 연구는 아직까지 수면에 대한 국내 연구자들의 관심이 부족한 가운데 유아의 수면문제가 실행기능 및 사회적 행동의 발달에 미치는 영향력을 발견함으로써, 유아기 수면의 중요성을 강조하였다. 또한, 유아의 수면문제와 사회적 행동 간의 관계를 설명해주는 기제로서 실행기능의 매개적 역할을 
확인하였다는 점에 의의가 있다. 본 연구의 결과는 유아가 건 강한 발달을 이루기 위해 최적의 수면이 필요하다는 것을 시 사하며, 이 시기 수면문제가 만성화되지 않도록 부모나 전문 가의 적절한 개입이 필요함을 강조한다. 본 연구의 결과는 유 아기 자녀를 둔 부모들을 위한 부모교육 프로그램과 같은 중 재 프로그램을 개발하는 데 기초자료로 활용될 수 있을 것으 로 기대된다.

\section{Acknowledgements}

This work was supported by the Ministry of Education of the Republic of Korea and the National Research Foundation of Korea (NRF-2016S1A3A2924375).

\section{Conflict of Interest}

No potential conflict of interest relevant to this article was reported.

\section{References}

\section{In English}

Anderson, P. (2002). Assessment and development of executive function during childhood. Child Neuropsychology, 8(2), 71-82. doi:10.1076/chin.8.2.71.8724

Astill, R. G., Van der Heijden, K. B., Van IJzendoorn, M. H., \& Van Someren, E. J. W. (2012). Sleep, cognition, and behavioral problems in school-age children: A century of research meta-analyzed. Psychological Bulletin, 138(6), 1109-1138. doi:10.1037/a0028204

Baron, R. M., \& Kenny, D. A. (1986). The moderator-mediator variable distinction in social psychological research: Conceptual, strategic, and statistical considerations. Journal of Personality and Social Psychology, 51(6), 1173-1182. doi:10.1037/0022-3514.51.6.1173

Basten, M., Tiemeier, H., Althoff, R. R., van de Schoot, R., Jaddoe, V. W. V., Hofman, A., . . . van der Ende, J. (2016). The stability of problem behavior across the preschool years: An empirical approach in the general population. Journal of Abnormal Child Psychology, 44(2), 393-404. doi:10.1007/ s10802-015-9993-y

Bates, J. E., Viken, R. J., Alexander, D. B., Beyers, J., \& Stockton,
L. (2002). Sleep and adjustment in preschool children: Sleep diary reports by mothers relate to behavior reports by teachers. Child Development, 73(1), 62-75. doi:10.1111/14678624.00392

Bernier, A., Beauchamp, M. H., Bouvette-Turcot, A. A., Carlson, S. M., \& Carrier, J. (2013). Sleep and cognition in preschool years: Specific links to executive functioning. Child Development, 84(5), 1542-1553. doi:10.1111/cdev.12063

Bordeleau, S., Bernier, A., \& Carrier, J. (2012). Longitudinal associations between the quality of parent-child interactions and children's sleep at preschool age. Journal of Family Psychology, 26(2), 254-262. doi:10.1037/a0027366

Brand, S., Hatzinger, M., Stadler, C., Bolten, M., von Wyl, A., Perren, S., . . Holsboer-Trachsler, E. (2015). Does objectively assessed sleep at five years predict sleep and psychological functioning at 14 years?: Hmm, yes and no! Journal of Psychiatric Research, 60, 148-155. doi:10.1016/ j.jpsychires.2014.10.007

Buckhalt, J. A., El-Sheikh, M., \& Keller, P. (2007). Children's sleep and cognitive functioning: Race and socioeconomic status as moderators of effects. Child Development, 78(1), 213231. doi:10.1111/j.1467-8624.2007.00993.x

Carlson, S. M. (2005). Developmentally sensitive measures of executive function in preschool children. Developmental Neuropsychology, 28(2), 595-616. doi:10.1207/s15326942 dn2802_3

Chaplin, T. M., \& Aldao, A. (2013). Gender differences in emotion expression in children: A meta-analytic review. Psychological Bulletin, 139(4), 735-765. doi:10.1037/a0030737

Cremone, A., de Jong, D. M., Kurdziel, L. B. F., Desrochers, P., Sayer, A., LeBourgeois, M. K., . . McDermott, J. M. (2017). Sleep tight, act right: Negative affect, sleep and behavior problems during early childhood. Child Development. Advance online publication. doi:10.1111/ cdev. 12717

Crick, N. R. (1995). Relational aggression: The role of intent attributions, feelings of distress, and provocation type. Developmental Psychology, 7(2), 313-322. doi:10.1017/ S0954579400006520

Crick, N. R., Casas, J. F., \& Mosher, M. (1997). Relational and overt aggression in preschool. Developmental Psychology, 33(4), 579-588. doi:10.1037/0012-1649.33.4.579

Dewald, J. F., Meijer, A. M., Oort, F. J., Kerkhof, G. A., \& Bögels, S. M. (2010). The influence of sleep quality, sleep duration and sleepiness on school performance in children and adolescents: A meta-analytic review. Sleep Medicine Reviews, 14(3), 179189. doi:10.1016/j.smrv.2009.10.004

El-Sheikh, M., Buckhalt, J. A., Mize, J., \& Acebo, C. (2006). Marital conflict and disruption of children's sleep. Child Development, 77(1), 31-43. doi:10.1111/j.1467-8624.2006.00854.x 
El-Sheikh, M., Kelly, R. J., Buckhalt, J. A., \& Hinnant, J. B. (2010). Children's sleep and adjustment over time: The role of socioeconomic context. Child Development, 81(3), 870883. doi:10.1111/j.1467-8624.2010.01439.x

Espy, K. A., Sheffield, T. D., Wiebe, S. A., Clark, C. A., \& Moehr, M. J. (2011). Executive control and dimensions of problem behaviors in preschool children. Journal of Child Psychology and Psychiatry, 52(1), 33-46. doi:10.1111/j.14697610.2010.02265.x

Garon, N., Bryson, S. E., \& Smith, I. M. (2008). Executive function in preschoolers: A review using an integrative framework. Psychological Bulletin, 134(1), 31-60. doi:10.1037/ 00332909.134.1.31

Gioia, G. A., Isquith, P. K., Guy, S. C., \& Kenworthy, L. (2000). Test review behavior rating inventory of executive function. Child Neuropsychology, 6(3), 235-238. Retrieved from http://www.riss.kr/link?id=O54385927

Girard, L. C., Pingault, J. B., Doyle, O., Falissard, B., \& Tremblay, R. E. (2017). Expressive language and prosocial behaviour in early childhood: Longitudinal associations in the UK Millennium Cohort Study. European Journal of Developmental Psychology, 14(4), 381-398. doi: 10.1080/17405629.2016.1215300

Goodlin-Jones, B., Tang, K., Liu, J., \& Anders, T. F. (2009). Sleep problems, sleepiness and daytime behavior in preschool-age children. Journal of Child Psychology and Psychiatry, 50(12), 1532-1540. doi:10.1111/j.1469-7610.2009.02110.x

Gregory, A. M., Rijsdijk, F. V., Lau, J. Y., Dahl, R. E., \& Eley, T. C. (2009). The direction of longitudinal associations between sleep problems and depression symptoms: A study of twins aged 8 and 10 years. Sleep, 32(2), 189-199. Retrieved from http://www.riss.kr/link?id=O50852885

Hala, S., Hug, S., \& Henderson, A. (2003). Executive function and false-belief understanding in preschool children: Two tasks are harder than one. Journal of Cognition and Development, 4(3), 275-298. doi:10.1207/S15327647JCD0403_03

Hale, L., Berger, L. M., LeBourgeois, M. K., \& Brooks-Gunn, J. (2011). A longitudinal study of preschoolers' languagebased bedtime routines, sleep duration, and well-being. Journal of Family Psychology, 25(3), 423-433. doi:10.1037/ a0023564

Hay, D. F. (2007). The gradual emergence of sex differences in aggression: Alternative hypotheses. Psychological Medicine, 37(11), 1527-1537. doi:10.1017/S0033291707000165

Hirshkowitz, M., Whiton, K., Albert, S. M., Alessi, C., Bruni, O., DonCarlos, L., . . . Hillard, P. J. A. (2015). National sleep foundation's sleep time duration recommendations: Methodology and results summary. Sleep Health, 1(1), 4043. doi:10.1016/j.sleh.2014.12.010

Hoffman, C. D., Sweeney, D. P., Lopez-Wagner, M. C., Hodge,
D., Nam, C. Y., \& Botts, B. H. (2008). Children with autism: Sleep problems and mothers' stress. Focus on Autism and Other Developmental Disabilities, 23(3), 155-165. doi: $10.1177 / 1088357608316271$

Hughes, C., \& Ensor, R. (2008). Does executive function matter for preschoolers' problem behaviors? Journal of Abnormal Child Psychology, 36(1), 1-14. doi:10.1007/s10802-0079107-6

Hughes, C., \& Ensor, R. (2011). Individual differences in growth in executive function across the transition to school predict externalizing and internalizing behaviors and self-perceived academic success at 6 years of age. Journal of Experimental Child Psychology, 108(3), 663-676. doi:10.1016/ j.jecp.2010.06.005

Huyder, V., \& Nilsen, E. S. (2012). A dyadic data analysis of executive functioning and children's socially competent behaviours. Journal of Applied Developmental Psychology, 33(4), 197-208. doi:10.1016/j.appdev.2012.05.002

Isquith, P. K., Gioia, G. A., \& Espy, K. A. (2004). Executive function in preschool children: Examination through everyday behavior. Developmental Neuropsychology, 26(1), 403-422. doi:10.1207/s15326942dn2601_3

Jenni, O. G., Molinari, L., Caflisch, J. A., \& Largo, R. H. (2007). Sleep duration from ages 1 to 10 years: Variability and stability in comparison with growth. Pediatrics, 120(4), 769-776. http://www.riss.kr/link?id=O47911478

Jones, K., \& Harrison, Y. (2001). Frontal lobe function, sleep loss and fragmented sleep. Sleep Medicine Reviews, 5(6), 463475. doi:10.1053/smrv.2001.0203

Keefe-Cooperman, K., \& Brady-Amoon, P. (2014). Preschooler sleep patterns related to cognitive and adaptive functioning. Early Education and Development, 25(6), 859-874. doi:10.1 080/10409289.2014.876701

Kim, S., Nordling, J. K., Yoon, J. E., Boldt, L. J., \& Kochanska, G. (2013). Effortful control in "hot" and "cool" tasks differentially predicts children's behavior problems and academic performance. Journal of Abnormal Child Psychology, 41(1), 43-56. doi:10.1007/s10802-012-9661-4

Komada, Y., Abe, T., Okajima, I., Asaoka, S., Matsuura, N., Usui, A., ... Inoue, Y. (2011). Short sleep duration and irregular bedtime are associated with increased behavioral problems among Japanese preschool-age children. The Tohoku Journal of Experimental Medicine, 224(2), 127-136. doi:10.1017/ S0033291707000165

Kouros, C. D., \& El-Sheikh, M. (2015). Daily mood and sleep: Reciprocal relations and links with adjustment problems. Journal of Sleep Research, 24(1), 24-31. doi:10.1111/ jsr.12226

Lam, J. C., Mahone, E. M., Mason, T. B. A., \& Scharf, S. M. (2011). The effects of napping on cognitive function in preschoolers. 
Journal of Developmental and Behavioral Pediatrics, 32(2), 90-97. doi:10.1097/DBP.0b013e318207ecc7

Lam, P., Hiscock, H., \& Wake, M. (2003). Outcomes of infant sleep problems: A longitudinal study of sleep, behavior, and maternal well-being. Pediatrics, 111(3), 203-207. Retrieved from http://www.pediatrics.org/cgi/content/full/111/3/ e203

Lavigne, J. V., Arend, R., Rosenbaum, D., Smith, A., Weissbluth, M., Binns, H. J., \& Christoffel, K. K. (1999). Sleep and behavior problems among preschoolers. Journal of Developmental \& Behavioral Pediatrics, 20(3), 164-169.

Lehmkuhl, G., Wiater, A., Mitschke, A., \& Fricke-Oerkermann, L. (2008). Sleep disorders in children beginning school: Their causes and effects. Deutsches Ärzteblatt International, 105(47), 809-814. doi:10.3238/arztebl.2008.0809

Mindell, J. A., Kuhn, B., Lewin, D. S., Meltzer, L. J., \& Sadeh, A. (2006). Behavioral treatment of bedtime problems and night wakings in infants and young children. Sleep, 29(10), 1263-1276. Retrieved from http://psycnet.apa.org/ psycinfo/2007-13597-002

Owens, J. A., Spirito, A., \& McGuinn, M. (2000). The Children's Sleep Habits Questionnaire (CSHQ): Psychometric properties of a survey instrument for school-aged children. Sleep, 23(8), 1043-1051.

Pollock, J. I. (1994). Night-waking at five years of age: Predictors and prognosis. The Journal of Child Psychology and Psychiatry, 35(4), 699-708. doi:10.1111/j.1469-7610.1994. tb01215.x

Quach, J., Hiscock, H., Ukoumunne, O. C., \& Wake, M. (2011). A brief sleep intervention improves outcomes in the school entry year: A randomized controlled trial. Pediatrics, 128(4), 692-701. doi:10.1542/peds.2011-0409

Raaijmakers, M. A. J., Smidts, D. P., Sergeant, J. A., Maassen, G. H., Posthumus, J. A., Van Engeland, H., \& Matthys, W. (2008). Executive functions in preschool children with aggressive behavior: Impairments in inhibitory control. Journal of Abnormal Child Psychology, 36(7), 1097-1107. doi:10.1007/ s10802-008-9235-7

Reid, G. J., Hong, R. Y., \& Wade, T. J. (2009). The relation between common sleep problems and emotional and behavioral problems among 2-and 3-year-olds in the context of known risk factors for psychopathology. Journal of Sleep Research, 18(1), 49-59. doi:10.1111/j.1365-2869.2008.00692.x

Rhoades, B. L., Greenberg, M. T., \& Domitrovich, C. E. (2009). The contribution of inhibitory control to preschoolers' socialemotional competence. Journal of Applied Developmental Psychology, 30(3), 310-320. doi:10.1016/j.appdev.2008.12.012

Sadeh, A. (2007). Consequences of sleep loss or sleep disruption in children. Sleep Medicine Clinics, 2(3), 513-520. doi:10.1016/ j.jsmc.2007.05.012
Sadeh, A., Alster, J., Urbach, D., \& Lavie, P. (1989). Actigraphically based automatic bedtime sleep-wake scoring: Validity and clinical applications. Journal of Ambulatory Monitoring, 2(3), 209-216. Retrieved from https://www.researchgate. net/profile/Doron_Urbach/publication/281455300_ Actigraphically-based_automatic_bedtime_sleepwake_scoring_Validity_and_clinical_applications/ links/55e8c97d08ae3e12184351b2.pdf

Sadeh, A., De Marcas, G., Guri, Y., Berger, A., Tikotzky, L., \& BarHaim, Y. (2015). Infant sleep predicts attention regulation and behavior problems at 3-4 years of age. Developmental Neuropsychology, 40(3), 122-137. doi:10.1080/87565641.2 014.973498

Scharf, R. J., Demmer, R. T., Silver, E. J., \& Stein, R. E. K. (2013). Nighttime sleep duration and externalizing behaviors of preschool children. Journal of Developmental \& Behavioral Pediatrics, 34(6), 384-391. doi:10.1097/DBP. 0b013e31829a7a0d

Simola, P., Liukkonen, K., Pitkäranta, A., Pirinen, T., \& Aronen, E. T. (2014). Psychosocial and somatic outcomes of sleep problems in children: A 4-year follow-up study. Child: Care, Health, and Development, 40(1), 60-67. doi:10.1111/ j.1365-2214.2012.01412.x

Touchette, É., Petit, D., Séguin, J. R., Boivin, M., Tremblay, R. E., \& Montplaisir, J. Y. (2007). Associations between sleep duration patterns and behavioral/cognitive functioning at school entry. Sleep, 30(9), 1213-1219.

Tremblay, R. E., \& Nagin, D. S. (2005). The developmental origins of physical aggression in humans. In R. E. Tremblay, W. W. Hartup, \& J. Archer (Eds.), Developmental origins of aggression (pp. 83-106). New York, NY: The Guilford Press.

Vaughn, B. E., Elmore-Staton, L., Shin, N., \& El-Sheikh, M. (2015). Sleep as a support for social competence, peer relations, and cognitive functioning in preschool children. Behavioral Sleep Medicine, 13(2), 92-106. doi:10.1080/154 02002.2013.845778

Whalen, D. J., Gilbert, K. E., Barch, D. M., Luby, J. L., \& Belden, A. C. (2017). Variation in common preschool sleep problems as an early predictor for depression and anxiety symptom severity across time. Journal of Child Psychology and Psychiatry, 58(2), 151-159. doi:10.1111/jcpp.12639

Williams, K. E., Berthelsen, D., Walker, S., \& Nicholson, J. M. (2017). A developmental cascade model of behavioral sleep problems and emotional and attentional self-regulation across early childhood. Behavioral Sleep Medicine, 15(1), 1-21. doi:10.1080/15402002.2015.1065410

Yokomaku, A., Misao, K., Omoto, F., Yamagishi, R., Tanaka, K., Takada, K., \& Kohyama, J. (2008). A study of the association between sleep habits and problematic behaviors in preschool children. Chronobiology International, 25(4), 
549-564. doi:10.1080/07420520802261705

Zelazo, P. D. (2004). The development of conscious control in childhood. Trends in Cognitive Sciences, 8(1), 12-17. doi:10.1016/j.tics.2003.11.001

Zelazo, P. D., \& Müller, U. (2002). Executive function in typical and atypical development. In U. Goswami (Ed.), Handbook of childhood cognitive development (pp. 445-469). Oxford, UK: Blackwell.

Zelazo, P. D., Müller, U., Frye, D., Marcovitch, S., Argitis, G., Boseovski, J., . . . Carlson, S. M. (2003). The development of executive function in early childhood. Monographs of the Society for Research in Child Development, 68(3), 1-151. Retrieved from http://www.jstor.org/stable/1166202

\section{In Korean}

Choi, E. A., \& Song, H. N. (2015). The effect of temperament at age 3 years on peer interaction at age 4 years: The serial dual mediating effect of sleep problem and attention. Journal of Korean Council for Children \& Right, 19(3), 463-490. Retrieved from http://www.newnonmun.com/ article $=10749385$

Do, H. J. (2009) A Study on the relationship between quality of sleep and behavior problems among young children (Master's thesis). Retrieved from http://www.riss.kr/ link?id=T11681530

Doh, H. S., Shin, N., Kim, M. J., Park, B. K., \& Na, J. H. (2012). The mediating effect of maternal abuse and neglect on the relationship between socioeconomic status and preschoolers' social behavior. Journal of Korean Home Management Association, 30(5), 107-119. Retrieved from http://www. dbpia.co.kr/Journal/ArticleDetail/NODE02029189

Hwang, H. (2016). The effects of young children's sleeping and eating habits on the emotional and behavioral problems. Journal of Future Early Childhood Education, 23(2), 299318.

Kim, B. Y. (2015). The effect of children's executive function, selfesteem and emotional intelligence on peer competence (Doctoral Dissertation). Retrieved from http://www.riss.kr/ link?id=T13819240

Kim, J. (2015). Relationship between napping and nocturnal sleep in 4-year-old children attending nursery school or kindergarten. The Korean Journal of the Human Development, 22(1), 1-20. Retrieved from http://www.newnonmun.com/ article $=191697$

Kim, M.-J. (2008). The development and effects of intervention program for aggressive young children: Focus on social skills training program and parent education (Doctoral Dissertation). Retrieved from http://www.riss.kr/ link?id=T11204592
Kim, S. J. (2015). A study of the association between sleep habits and cognitive, emotional, behavioral outcomes in preschool children. Journal of Korean Council for Children and Rights, 19(3), 319-341. Retrieved from http://www.newnonmun. $\mathrm{com} /$ article $=10749379$

Kim, S.-M., \& Kim, Y.-H. (2015) Effects of mother's marital relationship, depression, somatic symptoms, and sleep quality on children's sleep \& behavioral problems. Journal of Early Childhood Education \& Educare Welfare, 19(3), 219-243.

Kim, Y., \& Lee, K.-S. (2011). A study on sleep characteristics, sleep problems and their relationship with obesity in school aged children. The Korean Journal of Rehabilitation Psychology, 18(2), 87-109. Retrieved from http://www.dbpia.co.kr/ Journal/ArticleDetail/NODE01707834

Kim, Y.-H. (2015). Nighttime sleep duration and preschool children's behavioral problems. Korean Journal of Early Childhood Education, 35(1), 351-375.

Kong, Y. S., \& Lim, J. Y. (2012a). The effect of preschooler's temperament and maternal parenting attitude on preschooler's problem and prosocial behaviors: Focusing on the mediating effect of cool executive function. Korean Journal of Early Childhood Education, 32(2), 351-376.

Kong, Y. S., \& Lim, J. Y. (2012b). The relationships between preschooler's temperament, maternal parenting attitude, preschooler's problem and prosocial behaviors. The Journal of Child Education, 21(4), 135-152.

Kong, Y. S., \& Lim, J. Y. (2013). The effects of temperament and executive function on preschooler's externalizing and internalizing problems: Focusing on testing Latzman's problem behavior theory. The Journal of Child Education, 22(4), 5-24.

Min, S. H. (2009). The effects of maternal responses, preschooler's narrative representations, inhibition, and emotional regulation on preschoolers' physical and relational aggression. The Korean Journal of the Human Development, 16(1), 21-40. Retrieved from http://www.newnonmun.com/article=18948

Oh, Y. J., \& Lee, J. S. (2014). A study on effects of young children's sleeping hours on their maladjustment to kindergarten. Korean Society for Early Childhood Physical Education, 15(1), 41-49.

Park, H. Y., \& Lee, Y. (2013). Development of executive function in 3-7 year Olds: Analyses by age and maternal employment. The Korean Journal of Developmental Psychology, 26(1), 137-155. Retrieved from http://www. dbpia.co.kr/Journal/ArticleDetail/NODE06375285

Seo, J., \& Park, H. (2011). The effects of emotional intelligence on executive function: A comparison between normal children and attention deficit children. The Society for Cognitive Enhancement and Intervention, 2(1), 99-127. Retrieved 
from http://www.newnonmun.com/article $=53883$

Shin, Y. (2008). Physical and relational aggression in preschoolers:

Gender differences and links to language ability and social competence. Korean Journal of Early Childhood Education, 28(2), 95-111.

Yoo, R. H., \& Kim, S. H. (2017). The relationship between mothers' affective parenting and preschoolers' peer competence: Mediating effects of preschoolers' executive function and emotion regulation. Korean Journal of Child Studies, 38(2), 67-79. Retrieved from http://www.dbpia. co.kr/Journal/ArticleDetail/NODE07163956

You, S.-O., \& Cho, Y.-N. (2014). The effect of young children's sleep quality on emotional regulation and aggression. Journal of Parent Education, 6(1), 21-40.

\section{ORCID}

Nana Shin

Bokyung Park

Minjoo Kim

Kibong Yun

Sun-Young Yoon http://orcid.org/0000-0002-7869-6875

http://orcid.org/0000-0002-8194-1675

http://orcid.org/0000-0003-2969-079X

http://orcid.org/0000-0001-5065-4297

http://orcid.org/0000-0002-4320-2388
Received April 30, 2017

Revision received June 10, 2017

Accepted June 19, 2017 